\title{
Entrepreneurial Orientation and Firm Performance of Tourist Accommodation Establishment in Ghana
}

\author{
Edward Nii Amar Amarteifio*, Senyo Agbeblewu \\ Centre for Entrepreneurship and Small Enterprise Development, School of Business, University of Cape Coast, Cape Coast, Ghana \\ Email: *eamarteifio@ucc.edu.gh, senyo.agbeblewu@ucc.edu.gh
}

How to cite this paper: Amarteifio, E. N. A., \& Agbeblewu, S. (2020). Entrepreneurial Orientation and Firm Performance of Tourist Accommodation Establishment in Ghana. Open Journal of Business and Management, 8, 1619-1640.

https://doi.org/10.4236/ojbm.2020.84103

Received: February 8, 2020

Accepted: July 17, 2020

Published: July 20, 2020

Copyright (c) 2020 by author(s) and Scientific Research Publishing Inc. This work is licensed under the Creative Commons Attribution International License (CC BY 4.0).

http://creativecommons.org/licenses/by/4.0/

\begin{abstract}
Entrepreneurial Orientation in recent years is considered as an important area that influences the performance of most firms. It is evident in research that there is a strong correlation between performance and entrepreneurial orientation. Originating from the resource based view, entrepreneurial orientation and firm resources have been identified as important variables that impact on the performance of entrepreneurial firms. In the Central region, tourist accommodation and lodging establishments are very lucrative investments that generate a lot of revenues and taxes for owner/managers and the state respectively. These lodging facilities provide some form of employment for over 1800 workers. Most businesses and suppliers within the catchment area also depend on these lodgment facilities and its survival is of utmost importance to them. There is an intense competition from globalization resulting in increased volatility in business environments worldwide. Inability to adapt to such volatility threatens the survival and growth of entrepreneurial ventures such as tourist accommodation establishments. The explanatory survey was carried out in the Central Region, one of Ghana's ten administrative regions and home to about 142 licensed lodging facilities, comprising 3 star, 2 star, 1 star, guest houses, budget hotels and a hostel where 113 were randomly selected. The study revealed that managers were highly proactive but exhibited low levels of the other Entrepreneurial Orientation dimensions, particularly competitive aggressiveness and risk taking. It was therefore established that being innovative, proactive, taking risks and being an autonomous leader impacts slight on financial performance. Therefore, to improve the financial performance of their businesses, key decision makers must be more competitively and comparatively aggressive by intensifying efforts to outperform their competitors.
\end{abstract}




\section{Keywords}

Entrepreneurial Orientation, Firm Performance, Accommodation

\section{Introduction}

Entrepreneurial Orientation (EO) has recently been identified as one of the most important stimuli for a firm's performance. Research has shown that high growth and performance correlates with a firm's entrepreneurial orientation. Hence, growth and performance can be associated with innovativeness, pro-activeness and risk-taking behaviour of the firm, which refers to an entrepreneurial orientation (EO) dimension. The correlation between the entrepreneurial orientation (EO) of the firm and its performance has been widely discussed, conceptually (Covin \& Slevin, 1991; Lumpkin \& Dess, 1996) and empirically (Wiklund \& Shepherd, 2005; Covin \& Slevin, 1989; Lumpkin \& Dess, 2001). However, a lot of questions remain unresolved (Moreno \& Cassilas, 2008). Given the competitive conditions faced by firms in today's global economy, EO-performance relationship is multidimensional constructs as suggested by Lumpkin and Dess (1996). The debate on the relationship between entrepreneurial orientation and firm performance was stirred, for years, in the research community in management science. It is not yet closed insofar as it provokes reflection on researchers until now.

This relationship has been studied directly or indirectly (Arbaugh, Cox, \& Camp, 2009; Kreiser \& Davis, 2010; Grande et al., 2011; Hameed, 2011; Poon et al., 2006; Lumpkin, Brigham, \& Moss, 2010; Su, Xie, \& Li, 2011), through the inclusion of the moderating effect of several factors on this relationship. Some of the results point to a positive relationship between these two concepts (Hult, Hurley, \& Knight, 2004; Keh, Nguyen, \& Ng, 2007; Lee, Lee, \& Pennings, 2001; Sharma \& Dave, 2011; Smart \& Conant, 1994; Swierezek \& Thai, 2003; Wiklund, 1999; Wiklund \& Sphephered, 2005; Yusuf, 2002), and others show a negative relationship (Hart, 1992). These relationships have affected overall business in general. The majority of studies were conducted in developed countries. However, very few studies have concern for emerging countries, like Ghana without giving a conclusive result. In this regard, we can cite for example the work of Su, Xie, and Li (2011), Sharma \& Dave (2011), and Tang \& Tang (2012).

From a socio-psychological perspective, entrepreneurial orientation has been described as the set of personal psychological traits, values, attributes and attitudes strongly associated with a motivation to engage in entrepreneurial activity (Naldi, Nordqvist, Sjöberg, \& Wiklund, 2007). This description derives from a combination of related theories identifying the basis of $\mathrm{EO}$ and associating the concept with firm performance. These theories include the motivational/acquired needs theory, psychological theory, sociological theory and entrepreneurship innovation theories. EO has also been linked to the economic theory comprising 
the demand and supply sub-theories. Firm performance is seen as both financial and non-financial, and this is measured as viewed from three theoretical approaches namely, the stakeholder/constituency approach, systems resource approach and the goal approach (Amarteifio, 2014; Boohene, 2006). The stakeholder/constituency approach perceives performance as the extent to which the expectations of key stakeholders are met (Ford \& Schellenberg, 1982). The systems resource approach measures a firm's ability to obtain necessary resources to maintain its systems (Lachman \& Wolfe, 1997) while the goal approach measures progress made towards the attainment of organizational set goals (Cron, Bruton, \& Slocum Jr., 2006).

A case in point is the performance of tourist accommodation establishments in Ghana, also known as lodging establishments. Following the divestiture of state interests in the hospitality industry, entrepreneurially oriented management practices coupled with infrastructure improvement and staff training, have yielded dividends for the sub-sector (Mensah, 2009). Occupancy rates and employment figures have shot up with lodging ventures alone accounting for a third of the US $\$ 1.875$ billion revenue, generated by the tourism industry in 2010 (World Travel and Tourism Council [WTTC], 2011). Numbers of licensed lodging facilities, guest rooms and beds have also risen. The Central Region has been described as Ghana's tourism hub. Its palm-fringed beaches, historic forts and castles, natural attractions and exciting festivals draw thousands of foreign and domestic tourists to the region annually (Ghana Tourism Authority [GTA], 2011). Five grade categories of privately owned lodging establishments, serve as temporal dwelling places for both leisure and business tourists in the region. These facilities, 143 of which were licensed to operate in 2011, provide comfort, security, catering, recreation, business and transport services for guests.

In the Central region, tourist accommodation and lodging establishments are very lucrative investments that generate a lot of revenues and taxes for owners/managers and the state respectively. These lodging facilities provide some form of employment for over 1800 workers, engaged in various capacities such as administrators, caterers, housekeepers, etc. (GTA, 2011). Most businesses and suppliers within the catchment area also depend on these lodgment facilities and its survival is of utmost importance to them. The performance of these facilities impacts on the socio-economic development of the Central Region and also contributing to the development of the entire eco-tourism industry in Ghana. There is an intense competition from globalization resulting in increased volatility in business environments worldwide. Inability to adapt to such volatility threatens the survival and growth of entrepreneurial ventures such as tourist accommodation establishments. Some consequences sometimes include low level income and tax revenues, job losses and some setbacks in efforts to alleviate or reduce poverty, particularly in developing countries which Ghana is not excluded (WTTC, 2011). In Ghana, the likely impact of such circumstances on the performance of lodging establishments in the Central Region is a cause for con- 
cern.

Entrepreneurial orientation has been identified as an essential variable influencing the performance of entrepreneurial firms (Chen, Tzeng, Ou, \& Chang, 2007; Awang, Asghar, \& Subari, 2010). The relevance of this assertion to lodging establishments in the Central Region of Ghana remains unclear for two major reasons. Firstly, the formulation, testing, development and a bulk of the research on the resource based view and entrepreneurial orientation were mainly carried among manufacturing-related ventures in the developed North American, European and more recently, Asian countries (Wang, 2008). This study sought to fill this gap by examining the effect of EO on the performance of lodging establishments in the Central Region of Ghana.

\section{Literature Review and Hypotheses Development}

\section{Theoretical framework of the study}

This study draws inspiration from the resource-based view (RBV) in explaining the performance of firms. The RBV focuses on the heterogeneity of resources and its role in the creation of competitive and comparative advantage for firms. The strategic adaptation theory relates to the use of capabilities in aligning firm resources to meet changes in the external environment. Theories of entrepreneurship trace the factors influencing entrepreneurship.

\subsection{The Resource-Based View (RBV)}

The resource-based view highlights the role of a firm's internal characteristics and its environment in determining performance (Bruderl, Preisendorfer, \& Ziegler, 1992). It regards a firm as a composition of heterogeneous resources with a potential of creating valuable capabilities which will inure to a firm's advantage (Caldeira \& Ward, 2003; Wernerfelt, 1995). The RBV thus enhances understanding of how firms attain and sustain competitive advantage via resource heterogeneity (Thornhill \& Amit, 2003).

Penrose (1959), in one of the earliest contributions to the RBV, described a firm as a set of entrepreneurial and managerial resources. These resources render services which become inputs in the productive process (Barney, 1991). The diversity of the services rendered by these resources, results in heterogeneity, which distinguishes one firm from another (Peteraf, 1993). The distinction gives a firm a competitive edge which can be exploited to enhance performance (Lerner \& Almor, 2002). According to Edelman, Brush and Manolova (2008), the RBV simply asserts that performance differences among firms derive from variations in the efficiency with which they combine their resources.

Barney (1991) explained further that resources are able to provide sustained competitive advantage because they are valuable, rare, inimitable, and non-substitutable. These resources, according to Wernerfelt (1995) are strengths and weaknesses in the form of tangible and intangible assets, tied semi-permanently to a firm. Tangible assets, according to Miller and Shamsie (1996), are property-based while intangi- 
ble assets are knowledge-based. Of the two, intangible assets are more likely to result in sustained competitive advantage due to their unidentifiable nature, which makes them difficult to replicate (Miller \& Shamsie, 1996).

\subsection{Entrepreneurial Orientation and Performance}

Entrepreneurial orientation, according to Mintzberg (1973), is a firm level phenomenon emanating from the strategy-making process literature. Strategy-making is an organisation-wide phenomenon incorporating planning, analysis, decision making and many aspects of an organisation's culture, value system and mission (Hart, 1992). Specifically, entrepreneurial orientation is grounded in the strategic choice perspective, which asserts that new-entry opportunities can be successfully exploited by purposeful enactment (Van de Ven \& Poole, 1995). After the successful establishment of the venture, there is the need to constantly monitor, identify and adjust a venture's activities to suit changes in the external environment (Burgelman \& Grove, 1996). This process is referred to as strategic adaptation. Entrepreneurial orientation has also been viewed from a socio-psychological perspective. In this regard, the concept is perceived as a construct that addresses the set of personal psychological traits, values, attributes, and attitudes strongly associated with a motivation to engage in entrepreneurial activities (Naldi, Nordqvist, Sjöberg, \& Wiklund, 2007). EO thus reflects an interplay of economic and socio-psychological factors. The socio-psychological theories comprise: motivational/acquired needs, psychological, sociological and entrepreneurship innovation theories.

Based on Miller's (1983) three-dimensional construct of innovativeness, proactiveness and risk taking, Covin and Slevin (1989) developed a nine-item instrument to measure entrepreneurial orientation. The measurement indicators, comprising five items adapted from Khandwalla (1977) and Miller and Friesen (1982) and four by Covin and Slevin (1989), remains to date, the most widely applied measurement for Miller's (1983) three-dimensional model. Researchers including Becherer and Maurer (1997), Dickson and Weaver (2008) and Barringer and Bluedorn (1999) applied the construct in their empirical studies. The levels of entrepreneurial orientation were arrived at using mean ratings obtained on a scale. In spite of its wide appeal, criticism has been levelled against the above scale regarding its labelling of items and its mix of past behaviour with current attitudes (Wiklund \& Shepherd, 2003). Measurement of competitive aggressiveness and autonomy has been based on Lumpkin and Dess's (1996) characterization of the two dimensions. Each of the two dimensions has been measured using a three-item instrument. This brings to fifteen, the total number of indicators used in measuring all the five dimensions of entrepreneurial orientation discussed above. All fifteen scale-items have been proven to be valid and reliable as reported from a meta-analysis carried out by Rauch et al. (2011).

The entrepreneurship literature is replete with evidence of a positive relationship between EO and firm performance (Anderson \& Eshima, 2013; Wang, 2008; 
Wiklund \& Shepherd, 2005; Lumpkin \& Dess, 1996). Entrepreneurial orientation enhances a firm's ability to identify opportunities with potentially rewarding returns, to target premium market segments, obtain first mover advantages and ultimately improved results (Fairoz, Hirobumi, \& Tanaka, 2010; Wiklund \& Sheperd, 2005). Firms therefore achieve sustained higher performance as they become more entrepreneurially oriented (Fatoki et al., 2012; Yeboah, 2011).

According to Dimitratos, Lioukas and Carter (2004), where performance levels fall after the adoption of entrepreneurial orientation, firms may either strengthen their current levels of entrepreneurial orientation or change it all together, an option that could prove costly. On the other hand, past success attributable to the adoption of high levels of entrepreneurial orientation often becomes an incentive, enhancing a firm's commitment to entrepreneurial orientation (Irava \& Moores, 2010).

The reported levels of performance after the adoption of entrepreneurial orientation have generally been stronger for financial indicators such as return on sales, return on assets and return on capital (Awang, Khalid, Yusof, Kassim, Ismail, Zain, \& Madar, 2009). Nevertheless, some studies have recorded strong positive relationships between entrepreneurial orientation and non-financial indicators such as market share (Fairoz, Hirobumi, \& Tanaka, 2010). Contrarily, a few studies found no relationship between entrepreneurial orientation and firm performance (Sexton \& Bowman, 1991), while some even found a possible negative relationship, attributable to role imbalances between top management and organizational members (Hart, 1992). Fairoz, Hirobumi and Tanaka (2010) examined the EO-performance relationship. Following is a summary of their study. Fairoz, Hirobumi and Tanaka (2010) examined the influence of entrepreneurial orientation on the performance of twenty-five small and medium sized manufacturing enterprises in a district in Sri Lanka. They adopted Miller's (1983) three-dimensional model comprising innovativeness, proactiveness and risk-taking on grounds of proven reliability and validity.

For firm performance, Fairoz, Hirobumi and Tanaka relied on self-reported financial and non-financial business performance measures comprising sales growth, employment growth, profit (pre-tax), market share growth and owner/managers' satisfaction. The effects of firm age and ownership form were controlled for based on their reported influence on EO and resources. Fairoz, Hirobumi and Tanaka used semi-structured interviews as their major tool for gathering primary data. Quantitative and qualitative techniques were applied in analysing data collected. They adopted Khandwalla (1977) and Miller's (1983) nine-item measurement scale in measuring entrepreneurial orientation, using a five-category Likert scale ranging from 1: strongly disagree to 5: strongly agree. Levels of entrepreneurial orientation were established using mean scores obtained on the scale. Fairoz, Hirobumi and Tanaka relied on $\mathrm{R}^{2}$ values from simple regression to assess the relationship between composite EO and performance. They also applied simultaneous multiple regression techniques in deter- 
mining the contribution of each dimension of $\mathrm{EO}$ to variances in performance. Fairoz, Hirobumi and Tanaka further assessed the influence of EO on each of the selected performance indicators.

Both individual and composite dimensions of entrepreneurial orientation were found to have significant positive relationships with growth in market share ( $p$ $<0.05)$. Entrepreneurial orientation and proactiveness had significant positive relationship with overall firm performance at $(p<0.10)$ and $(p<0.05)$ respectively. Firms with higher entrepreneurial orientation achieved higher sales growth, profit and market share compared to those with low entrepreneurial orientation. Based on their findings, Fairoz, Hirobumi and Tanaka recommended improvements in the levels of innovativeness, proactiveness and risk taking by firms to protect and increase their market share and ultimately improve performance. They further recommended the acquisition of the right human and information resources to enhance levels of entrepreneurial orientation. It is therefore expected that EO will have a positive relationship with performance.

\subsection{Innovativeness and Performance}

Innovation literature claims that innovation is one of the key factors for firm success and survival (Jimenez \& Sanz-Valle, 2011; Bhuian et al., 2005; Cho \& Pucik, 2005; Damanpour \& Gopalaksihnan, 1998; Damanpour, 1996; Fiol, 1996; Wolfe et al., 1994) and sustainable competitive advantage (Standing \& Kiniti, 2011; Bartel \& Garud, 2009; Johannessen, 2009; Mumford \& Licuanan, 2004). The traditional explanation for the positive relationship between innovativeness and firm performance rests on Schumpeter (1934), he argued that innovative new products when first introduced to the market face limited direct competition and, as a result, allow firms to enjoy relatively high profits. Over time, these high profits are likely to erode due to imitation and competition, but firms that continue introducing innovative new products may be able to achieve high profitability for a sustained period (Sharma \& Lacey, 2004). Like many other scholars, Varis and Littunen (2010) argued that the ultimate reason for firms to engage in innovation activities is to improve firm performance and success. The impact of innovation activities on firm performance is also emphasized in Oslo Manual. In the study of Geroski et al. (1993) on 721 manufacturing firms in UK it was found that the number of innovations achieved by firms had a positive effect on their operating profit margin. Therefore, the hypothesis was developed as follows:

H1. There is a positive relationship between innovativeness and performance.

\subsection{Proactiveness and Performance}

Proactiveness which is the second dimension refers to the extent to which organisations attempt to lead rather than follow competitors in key business areas such as the introduction of new products, operating technologies and administrative techniques (Covin \& Slevin, 1986). Venkatraman (1989), similarly de- 
scribed proactiveness as a process of anticipating and acting on future needs via seeking new opportunities which ought not to relate to the present line of operations. Proactiveness suggests "a forward-looking perspective that is accompanied by innovative or new-venturing activity" (Lumpkin \& Dess, 1996: p. 146). Firms, which possessed this quality, were able to look for new business opportunities for the reason of improving their financial and non-financial performance during recession (Soininen, 2012). Casillas and Moreno (2010) indicated that higher proactiveness promotes higher growth rate in sales, simply because firms are more aggressive in searching and capturing business opportunities. True, Fairoz et al. (2010) also found that market share growth was significantly affected by proactiveness. This dimension, which is characterised by willingness to take high-risk actions, is also a vital contributor to new product performance (Avlonitis \& Salavou, 2007). In addition, Hughes and Morgan (2007) confirmed a significant correlation between proactiveness product performance and customer performance among young high-technological firms. As comparable to the previous dimension, the proactiveness-performance relationship has reached a consensus among the previous researchers. Therefore, the hypothesis was developed as follow:

H2. There is a positive relationship between proactiveness and performance.

\subsection{Risk-Taking and Performance}

Definitions for risk-taking as a dimension of EO converge around the issue of venturing into the unknown. Lumpkin and Dess (1996) define it as a willingness to assume risks such as borrowing heavily or investing huge resources in unknown ventures with reasonable chances of costly failures. Entrepreneurial risk may occur either at the firm or individual level (Sitkin \& Pablo, 1992). Firm level risk, also referred to as managerial risk, relates to decisions and choices with uncertain outcomes (Palmer \& Wiseman, 1999). Individual risk is however personal in nature and is influenced by a number of factors including results of past risk-taking activities (Thaler \& Johnson, 1990), level of optimism (Palich \& Bagby, 1992) and ability to perform under risky conditions (Slovic, 1993). Fairoz et al. (2010) recorded a positive significant relationship between risk and market share growth. On the contrary, Casillas and Moreno (2010) did not confirm that risk-taking positively influence growth. Hughes and Morgan (2007) also found no correlation between risk-taking and performance. Due to the inconsistencies of findings in existing studies, it indicated that influence of risk-taking on performance of firms required a re-examination. As such, the hypothesis below was constructed:

H3. There is a positive relationship between risk-taking and performance.

\subsection{Competitive Aggressiveness and Performance}

Stinchcombe (1965), asserts that young firms are particularly susceptible to the liability of newness in intensely hostile environments and must therefore take 
steps to establish legitimacy and power relative to suppliers, customers, and other competitors. This activity, which involves an intensified head-to-head posturing to outperform rivals, is referred to as competitive aggressiveness (Lumpkin \& Dess, 1996). Researchers who have included this dimension in their EO construct have confirmed its impact on firms' innovation performance (Madhoushi et al., 2011). On the contrary, Casillas and Moreno (2010) found no relationship between competitive aggressiveness and growth due to dual condition. Similar results were also obtained in Hughes and Morgan (2007). The contradicting results indicated the need to restudy the relationship that exists between competitive aggressiveness and performance. Hence:

H4. There is a positive relationship between competitive aggressiveness and performance.

\subsection{Autonomy and Performance}

Autonomy under entrepreneurial orientation refers to the willingness and ability to be self-directed in the pursuit of business opportunities (Lumpkin \& Dess, 1996). It reflects a tendency towards independent action by an individual or team aimed at bringing forth a business concept or vision and carrying it through to completion (Lee \& Peterson, 2000). The significant positive relationship between autonomy and firms' performance has been confirmed by Awang et al. (2009). However, such relationship was not proven by Casillas and Moreno (2010) and Hughes and Morgan (2007). Thus, the following hypothesis was formulated:

H5. There is a positive relationship between autonomy and performance.

\section{Methodology}

The explanatory survey was carried out in the Central Region, one of Ghana's ten administrative regions and home to about 142 licensed lodging facilities, comprising 3 star, 2 star, 1 star, guest houses, budget hotels and a hostel. After arriving at a figure of 113 using Krejcie and Morgan's (1970) table, specific facilities were selected using simple proportion, simple random and oversampling techniques. The three sampling techniques ensured the representation of all grade categories, an equal chance of each facility being included and an upward adjustment of underrepresented categories (see Table 1).

Primary and secondary sources were relied upon to provide data for the study. Data requirements, covering business and manager characteristics, entrepreneurial orientation, resources and performance were obtained from primary and secondary sources. Following a successful pretest involving 20 lodging establishments, a 57-item self-administered questionnaire, comprising close and open ended as well as Likert-scale-type questions, bordering on the variables of the study, were distributed to 113 selected lodging establishments. A total of 102 questionnaires, representing 90.3 percent of distributed questionnaires were retrieved after a six-week period. 
Table 1. Initial and adjusted sample sizes of participating lodging establishments.

\begin{tabular}{cccc}
\hline Grade & Population & Initial Sample & Adjusted Sample \\
\hline Three star & 3 & 2 & 3 \\
Two star & 8 & 6 & 8 \\
One star & 14 & 10 & 14 \\
Guest house & 10 & 7 & 10 \\
Budget & 106 & 77 & 77 \\
Hostel & 1 & 1 & 1 \\
Total & 142 & 103 & 113 \\
\hline
\end{tabular}

Source: Field data, 2011.

Data was analyzed quantitatively using descriptive and inferential statistics. Assessment of the levels of EO exhibited by managers was based on mean values ranging from 1 to 5 with 1 to 2.9 representing low levels and 3 to 5 representing high levels. This followed an assessment of the normality of distribution of the scores obtained using the significant (Sig.) values of the Kolmogorov-Smirnov statistic, the histogram and normal probability plots, as recommended by Tabachnick and Fidell (2007) and Pallant (2007).

The influences of the EO indicators, EO dimensions and composite EO on performance were assessed using multiple regression techniques after ensuring that underlying assumptions regarding sample size, linearity of variables, normality, homoscedasticity of residuals, multicollinearity and outliers. Assessments of the influences of EO indicators and dimensions on performance were done using the standard multiple regression technique, given its ability to permit simultaneous entry of multiple variables and explain their individual influences on a single dependent variable (Pallant, 2007). Beta $(\beta)$ values, partial correlation values $(\mathrm{r})$, co-efficient of determination $\left(\mathrm{R}^{2}\right)$ and corresponding significance levels ( $p$-values) were relied upon. The hierarchical multiple regression technique was utilized to assess the influence of composite EO on firm performance. Regression co-efficient $\left(\mathrm{R}^{2}\right)$ and variations in them $\left(\mathrm{R}^{2}\right.$ change) were relied upon. In testing for all relationships, firm age and ownership form were controlled for following evidence in the literature of their influence on EO and performance. All analysis was done using Statistical Product and Service Solutions (SPSS version 16.0).

\subsection{Reliability Test}

Reliability of a scale gives an indication of how free it is from random error (Pallant, 2007) or the extent to which the scale produces consistent results if repeated measures are taken. Two frequently used indicators of a scale's reliability are test-retest reliability (also referred to as temporal stability) and internal consistency (Tabachnick \& Fidell, 2007). In spite of the effectiveness of the test-retest approach in measuring stable personality traits such as one's entre- 
preneurial orientation (Pallant, 2007), likely reluctance of respondents to repeat participation, coupled with time and cost constraints, rendered it inappropriate for this survey.

Internal consistency on the other hand measures the degree to which all items on a scale, measure an underlying construct (Pallant, 2007). The Cronbach's alpha coefficient $(\alpha)$ with a recommended minimum value of 0.7 is the most common indicator for testing internal consistency (Nunnally, 1978). Tabachnick and Fidell (2007) and Pallant (2007) suggest an additional requirement of a minimum item-total correlation of 0.3 to further buttress the Cronbach's alpha coefficient. Both measures were adopted in testing for reliability of the instrument using Statistical Product and Service Solutions (SPSS) version 16.0.

The Cronbach's alpha coefficients obtained for the entrepreneurial orientation and firm performance scales were above 0.7 , suggesting very good internal consistency reliability. However, four items were removed from the EO construct as they scored lower than 0.3 on the item-total correlation. These were two indicators from the competitive aggressiveness dimension and one each from innovativeness and autonomy. The reliability coefficients obtained are presented in $\mathrm{Ta}$ ble 2 .

\subsection{Validity Testing}

Validity of the survey instrument was tested via the content and criterion validity approaches among others. As recommended by McDaniel and Gates (1996), content validity was ensured via operational definition of variables, review of literature, checking of scales with experts and pre-testing scales. Criterion validity which examined the degree of correlation among variables of a study (Aaker, Kumar, George, \& Day, 2001) was also ensured via regressing analysis involving the variables, results of which confirmed significant relationships.

As suggested by Malhotra et al. (1996), construct validity was established by testing for both convergent and discriminant validity (Malhotra et al., 1996). Convergent validity, a measure of the degree of homogeneity of items on a scale was established using principal component analysis, a commonly used factor extraction technique which reduces large numbers of scale items into smaller numbers of coherent sub-scales by identifying and clumping inter-correlated sets of variables (Pallant, 2007). Orthogonal rotation, a technique frequently

Table 2. Computed reliability coefficients for data collected during pilot study.

\begin{tabular}{cccc}
\hline Questionnaire Section & No. of Items & Sample Size & Cronbach's Alpha \\
\hline C-Entrepreneurial orientation & 11 & 19 & 0.882 \\
E-Firm performance & 8 & 19 & 0.833
\end{tabular}

Source: Field data, 2011. 
used by researchers in establishing discriminant validity was on the other hand achieved using varimax, the most commonly used orthogonal rotation method to maximise the factor loading on some variables and minimize others with high loadings (Hair, Bush, \& Ortinau, 2003; Pallant, 2007; Tabachnick \& Fidell, 2007).

\section{Results and Discussions}

\subsection{Entrepreneurial Orientation and Financial Performance}

The first objective of the study was to assess the influence of EO on the level of financial performance of the facilities. As EO, for purposes of this study, comprised five dimensions, a two-step approach was adopted to achieve this objective. The first step assessed the influence of each dimension of EO on financial performance, using the standard multiple regression technique. This technique permits a simultaneous entry of multiple independent variables into a single model, providing the contribution of each variable, to variances in the dependent variable (Pallant, 2007).

Going by the beta values, all five dimensions of EO contributed to the level of financial performance of the facilities (see Table 3 ). However, only competitive aggressiveness made a positive significant contribution $(\beta=0.255$; Sig. $=0.002)$ whiles that of risk taking was negative and insignificant $(\beta=-0.003$; Sig. $=$ 0.974). All dimensions, except competitive aggressiveness $(r=0.307)$, were weakly associated with financial firm performance $(\mathrm{r}<0.29)$. Risk taking had a weak negative association with financial performance. Competitive aggressiveness accounted for the most unique and only significant variance in the level of financial performance $\left(\mathrm{R}^{2}=0.045\right)$. The variance explained by the remaining dimensions was insignificant with risk taking accounting for no variance at all in the level of financial performance $\left(R^{2}=0.038\right)$. Firm age had no unique impact on financial performance while ownership form impacted very little on the dependent variable. As shown in Table 3, composite EO accounted for 57.1 percent of variations in firm financial performance, a figure enhanced by the influence of confounding variables, i.e. firm age and ownership form.

Table 3. Entrepreneurial orientation dimensions predicting firm financial performance.

\begin{tabular}{cccccc}
\hline Constant & Beta & t-stats & $p$-value & $\mathbf{R}$ & $\mathbf{R}^{2}$ \\
\hline Constant & & 2.512 & 0.014 & & 0.000 \\
Firm age & -0.02 & -0.276 & 0.783 & -0.028 & 0.007 \\
Ownership form & 0.098 & 1.261 & 0.21 & 0.129 & 0.18 \\
Innovativeness & 0.186 & 1.778 & 0.079 & 0.014 \\
Proactiveness & 0.278 & 2.298 & 0.024 & 0.231 & 0.024 \\
Risk taking & -0.003 & -0.033 & 0.974 & -0.003 & 0.000 \\
Competitive Aggressiveness & 0.255 & 3.128 & 0.002 & 0.307 & 0.045 \\
Autonomy & 0.164 & 1.729 & 0.087 & 0.176 & 0.014 \\
\hline
\end{tabular}

$\mathrm{R}^{2}=0.571 ; \mathrm{F}(7,94)=33.520, p<0.001$. Source: Field data, 2011 
Hierarchical multiple regression was utilized in eliminating the impact of the control variables to clarify the entrepreneurial orientation-financial performance relationship. The technique permits the entry of variables into a model, in a manner preferred by the researcher, thereby enabling a before and after comparison of results (Pallant, 2007). As shown in Table 4, firm age and ownership form together accounted for an initial 10.5 variation in firm financial performance with ownership form making a significant contribution $(\beta=0.339$; Sig. $=$ $0.001)$. The subsequent entry of $\mathrm{EO}$ in the second model saw a rise of 44.5 percent in firm financial performance $\left(\mathrm{R}^{2}=0.550\right.$; Sig. $\left.=0.000\right)$. The drop in the impact of EO from 57.1 percent to 44.5 percent confirms earlier assertions of the roles of firm age and ownership form in the EO-performance relationship. EO thus explained a 44.5 percent unique variances in the financial performance of the facilities, confirming the model in our conceptual framework as well as conclusions reached by this study.

\subsection{EO and Non-Financial Performance}

The second objective sought to examine the influence of EO on the non-financial performance of the facilities. As done in the first objective, an initial assessment was done to assess the influence of each of the dimensions of EO on non-financial performance, using the standard multiple regression technique. Proactiveness ( $\beta$ $=0.469$; Sig. $=0.000)$ and competitive aggressiveness $(\beta=0.304$; Sig. $=0.000)$ made the most significant contributions to non-financial performance of the facilities. The contribution of risk taking was negative and insignificant $(\beta=$ -0.057 ; Sig. $=0.580)$. In a similar fashion, proactiveness $(r=0.381)$ and competitive aggressiveness $(r=0.369)$ were the most associated with non-financial performance, albeit intermediate $(0.30 \geq \mathrm{r} \leq 0.49)$. Risk taking was negatively showed a negative association $(r=0.369)$. Regarding the unique variance independently explained by each dimension, proactiveness $\left(R^{2}=0.068\right)$ and competitive aggressiveness $\left(R^{2}=0.064\right)$ accounted for the most variance explaining 6.8 percent and 6.4 percent of variances in non-financial performance. The unique variances explained by the remaining dimensions were negligible (see Table 5).

Table 4. Hierarchical multiple regression analysis summary for firm age, ownership form and entrepreneurial orientation predicting firm financial performance.

\begin{tabular}{cccccc}
\hline Variable & Beta & t-stats & Sig & R Square & $\mathrm{R}^{2}$ Square \\
\hline Model 1 & & & & $\mathbf{0 . 1 0 5}$ & $\mathbf{0 . 1 0 5}$ \\
Firm age & -0.098 & -0.983 & 0.328 & & \\
Ownership & 0.339 & 3.399 & 0.001 & & \\
Form Constant & & 20.795 & 0.000 & & $\mathbf{0 . 4 4 5}$ \\
Model 2 & & & & $\mathbf{0 . 5 5 0}$ & \\
Firm age & 0.009 & -0.123 & 0.902 & & \\
Ownership & 0.078 & 1.030 & 0.305 & & \\
Form Entrepreneurial & 0.712 & 9.849 & 0.000 & 0.445 & \\
Orientation Constant & & 3.063 & 0.003 & & \\
\hline
\end{tabular}

Model 1: $\mathrm{R}^{2}=0.105(2,99)=5.777, p<0.01 ;$ Model 2: $\mathrm{R}^{2}=0.550(3,98)=39.923, p<0.01$. 
Table 5. Standardized multiple regression analysis summary for firm age, ownership form, entrepreneurial orientation dimensions predicting firm non-financial performance.

\begin{tabular}{cccccc}
\hline Variable & Beta & t-stats & $p$-value & $\mathbf{R}$ & $\mathbf{R}^{2}$ \\
\hline Constant & & 2.067 & 0.042 & & \\
Firm age & 0.051 & 0.732 & 0.466 & 0.075 & 0.002 \\
Ownership form & 0.100 & 1.331 & 0.186 & 0.136 & 0.008 \\
Innovativeness & 0.074 & 0.729 & 0.468 & 0.075 & 0.002 \\
Proactiveness & 0.469 & 3.991 & 0.000 & 0.381 & 0.068 \\
Risk taking & -0.057 & -0.555 & 0.58 & -0.057 & 0.001 \\
Competitive Aggressiveness & 0.304 & 3.848 & 0.000 & 0.369 & 0.064 \\
Autonomy & 0.063 & 0.688 & 0.493 & 0.071 & 0.002 \\
\hline
\end{tabular}

$\mathrm{R}^{2}=0.597 ; \mathrm{F}(7,94)=32.925, p<0.001$.

On the whole, 59.7 percent of the variation in non-financial performance was explained by composite EO. There was however the need to clarify the relationship by eliminating the possible impact of the control variables.

A comparison of the above results indicates that, being competitively aggressive impacts firm financial performance the most with variances explained by the remaining dimensions being insignificant. On the other hand, proactivity and competitive aggressiveness uniquely influence non-financial performance the most with the remaining dimensions accounting for only negligible variances in non-financial performance.

As done with financial performance, hierarchical multiple regression was utilized in eliminating the impact of the control variables on the EO-non-financial performance relationship. From model 1 of Table 6, firm age and ownership form accounted for 9.6 percent of variations in non-financial performance, albeit insignificantly $\left(R^{2}=0.096\right.$; Sig. $\left.=0.007\right)$. The percentage of variation rose by to 53.4 percent upon the subsequent introduction of EO into the second model $\left(\mathrm{R}^{2}\right.$ $=0.534$; Sig. $=0.000$ ), indicating a rise of 43.8 percent. This result implies that EO has a unique significant effect on firm non-financial performance, confirming the model. The fall in the influence of EO from the initial 59.7 percent to 43.8 percent also confirmed the long-standing assertion of the impact of firm age and ownership form on the EO-performance relationship. A comparison with the results obtained for financial performance indicates that the impact of EO was higher for financial performance compared to non-financial performance.

\section{Conclusion}

With regards to the first objective, the level of EO, particularly, competitive aggressiveness, exhibited by key decision makers, impacts positively on their firms' financial performance. Being innovative, proactive, taking risks and being an autonomous leader impact little on financial performance. For the second objective, being entrepreneurially oriented, particularly through proactivity and 
Table 6. Hierarchical multiple regression analysis summary for firm age, ownership form and entrepreneurial orientation predicting firm non-financial performance.

\begin{tabular}{cccccc}
\hline Variable & Beta & t-stats & Sig & $\mathrm{R}^{2}$ & $\mathrm{R}^{2}$ Change \\
\hline Model 1 & & & & 0.096 & $\mathbf{0 . 0 9 6}$ \\
Firm age & -0.016 & -0.162 & 0.872 & & \\
Ownership & 0.315 & 3.147 & 0.002 & & \\
Form Constant & & 20.036 & 0.000 & & \\
Model 2 & & & & 0.534 & 0.438 \\
Firm age & 0.072 & 0.991 & 0.324 & & \\
Ownership & 0.057 & 0.735 & 0.464 & & \\
Form Entrepreneurial & 0.706 & 9.592 & 0.000 & 0.438 & \\
Orientation Constant & & 2.708 & 0.008 & & \\
\hline & &
\end{tabular}

Model 1: $\mathrm{R}^{2}=0.096(2,99)=5.284, p<0.01$ Model 2: $\mathrm{R}^{2}=0.534(3,98)=37.428, p<0.01$.

competitive aggressiveness, enhances a firm's non-financial performance. Exercising autonomy by committing resources to novel ideas contributes little to enhancing a firm's non-financial performance. Regarding the third objective, initiating actions ahead of competitors and acting in anticipation of clients' future needs, are two indicators that uniquely influence the overall performance of a firm. Furthermore, as with financial and non-financial performance, being proactive in relation to client needs and also competitively aggressive towards competitors, give firms a competitive edge and ultimately enhance their overall performance.

\section{Recommendations}

To enhance the financial performance of their firms, key decision makers must be more competitively aggressive by intensifying efforts to outperform their competitors. In addition to that, managers must exhibit leadership through anticipating and preparing to meet the latent needs of their clients to enhance their non-financial performance. Beyond such preparation, decision makers must ensure speedy implementation of solutions to such needs ahead of competitors to enhance overall performance of their respective firms. Managers are also advised to enhance the growth of their facilities by being proactive and competitively aggressive and speed up implementation of their innovative ideas.

\section{Acknowledgements}

The earlier version of this paper was presented at the 75th Clute International Academic Conference on Business, Las Vegas, Nevada, October 8-12, 2017. I will like to thank Dr Otuo Serebour Agyemang, Dr Nana Yaw Oppong and Jennifer Secor for comments on the earlier draft.

\section{Conflicts of Interest}

The authors declare no conflicts of interest regarding the publication of this paper. 


\section{References}

Aaker, D. A., Kumar, V., \& George, Day, S. (2001). Marketing Research (7th. ed.). Hoboken, NJ: Wiley.

Amarteifio, E. N. A. (2014). Investment Readiness, Access to External Finance and Performance of SMEs in the Accra Metropolis. Unpublished Doctor of Philosophy Thesis, Cape Coast: University of Cape Coast.

Anderson, B. S., \& Eshima, Y. (2013). The Influence of Firm Age and Intangible Resources on the Relationship between Entrepreneurial Orientation and Firm Growth among Japanese SMEs. Journal of Business Venturing, 28, 413-429. https://doi.org/10.1016/j.jbusvent.2011.10.001

Arbaugh, J. B., Cox, L. W., \& Camp, S. M. (2009). Is Entrepreneurial Orientation a Global Construct? A Multi-Country Study of Entrepreneurial Orientation, Growth Strategy, and Performance. The Journal of Business Inquiry, 8, 12-25.

Avlonitis, G. J., \& Salavou, H. E. (2007). Entrepreneurial Orientation of SMEs, Product Innovativeness, and Performance. Journal of Business Research, 60, 566-575. https://doi.org/10.1016/j.jbusres.2007.01.001

Awang, A., Asghar, A. R. S., \& Subari, K. A. (2010). Study of Distinctive Capabilities and Entrepreneurial Orientation on Return on Sales among Small and Medium Agro-Based Enterprises (SMAEs) in Malaysia (Electronic Version). International Business Research, 3, No. 2. http://www.ccsenet.org/ibr

https://doi.org/10.5539/ibr.v3n2p34

Awang, A., Khalid, S. A., Yusof, A. A., Kassim, K. M., Ismail, M., Zain, R. S., \& Madar, A. R. S. (2009). Entrepreneurial Orientation and Performance Relations of Malaysian Bumiputera SMEs: The Impact of Some Perceived Environmental Factors. International Journal of Business and Management, 4, 84-96. https://doi.org/10.5539/ijbm.v4n9p84

Barney, J. (1991). Firm Resources and Sustained Competitive Advantage. Journal of Management, 17, 99-120. https://doi.org/10.1177/014920639101700108

Barringer, B. R., \& Bluedorn, A. C. (1999). The Relationship between Corporate Entrepreneurship and Strategic Management. Strategic Management Journal, 20, 421-444. https://doi.org/10.1002/(SICI)1097-0266(199905)20:5<421::AID-SMJ30>3.0.CO;2-O

Bartel, C., \& Garud, R. (2009). The Role of Narratives in Sustaining Organisational innovation. Organisation Science, 20, 107-117. https://doi.org/10.1287/orsc.1080.0372

Becherer, R. C., \& Maurer, J. G. (1997). The Moderating Effect of Environmental Variables on the Entrepreneurial and Marketing Orientation of Entrepreneur-Led Firms. Entrepreneurship Theory and Practice, 22, 47-58. https://doi.org/10.1177/104225879702200103

Bhuian, S. N., Menguc, B., \& Bell, S. J. (2005). Just Entrepreneurial Enough: The Moderating Effect of Entrepreneurship on the Relationship between Market Orientation and Performance. Journal of Business Research, 58, 9-17. https://doi.org/10.1016/S0148-2963(03)00074-2

Boohene, R. A. (2006). Tracking the Pathway: Explaining Gender Differences in Performance among Small Business Owners in a Transition Economy. Unpublished Doctor of Philosophy Thesis, Armidale: University of New England (Australia).

Brüderl, J., Preisendörfer, P., \& Ziegler, R. (1992). Survival Chances of Newly Founded Business Organizations. American Sociological Review, 57, 227-242.

https://doi.org/10.2307/2096207 
Burgelman, R. A., \& Grove, A. S. (1996). Strategic Dissonance. California Management Review, 38, 8-28. https://doi.org/10.2307/41165830

Caldeira, M. M., \& Ward J. M. (2003). Using Resource-Based Theory to Interpret the Successful Adoption and Use of Information Systems and Technology in Manufacturing Small and Medium-Sized Enterprises. European Journal of Information Systems, 12, 127-141. https://doi.org/10.1057/palgrave.ejis.3000454

Casillas, J. C., \& Moreno, A. M. (2010). The Relationship between Entrepreneurial Orientation and Growth: The Moderating Role of Family Involvement. Entrepreneurship \& Regional Development, 22, 265-291. https://doi.org/10.1080/08985621003726135

Chen, C., Tzeng, L., Ou, W., \& Chang, K. (2007). The Relationship among Social Capital, Entrepreneurial Orientation, Organizational Resources and Entrepreneurial Performance for New Ventures. Contemporary Management Research, 3, 213-232. https://doi.org/10.7903/cmr.90

Cho, H.-J., \& Pucik, V. (2005). Relationship between Innovativeness, Quality, Growth, Profitability, and Market Value. Strategic Management Journal, 26, 555-575. https://doi.org/10.1002/smj.461

Covin, J. G., \& Slevin, D. P. (1986). The Development and Testing of an Organization-Level Entrepreneurship Scale. In R. Ronstadt, J. A. Hornaday, R. Peterson, \& K. H. Vesper (Eds.), Frontiers of Entrepreneurship Research (pp. 628-639). Wellesley, MA: Babson College.

Covin, J. G., \& Slevin, D. P. (1989). Strategic Management of Small Firms in Hostile and Benign Environments. Strategic Management Journal, 10, 75-87. https://doi.org/10.1002/smj.4250100107

Covin, J. G., \& Slevin, D. P. (1991). A Conceptual Model of Entrepreneurship as Firm Behavior. Entrepreneurship Theory and Practice, 16, 7-26. https://doi.org/10.1177/104225879101600102

Cron, W. L., Bruton, G. D., \& Slocum Jr., J. W. (2006). Professional Service Ventures, Performance and the Gender Effect. Journal of Leadership and Organizational Studies, 12, 53-67. https://doi.org/10.1177/107179190601200304

Damanpour, F. (1996). Organizational Complexity and Innovation: Developing and Testing Multiple Contingency Models. Management Science, 42, 693-716. https://doi.org/10.1287/mnsc.42.5.693

Damanpour, F., \& Gopalakrishnan, S. (1998). Theories of Organizational Structure and Innovation Adoption: The Role of Environmental Change. Journal of Engineering and Technology Management, 15, 1-24. https://doi.org/10.1016/S0923-4748(97)00029-5

Dickson, P. H., \& Weaver, K. M. (2008). The Role of the Institutional Environment in Determining Firm Orientations towards Entrepreneurial Behavior. International Entrepreneurship and Management Journal, 4, 467-483. https://doi.org/10.1007/s11365-008-0088-x

Dimitratos, P., Lioukas, S., \& Carter, S. (2004). The Relationship between Entrepreneurship and International Performance: The Importance of Domestic Environment. International Business Review, 13, 19-41. https://doi.org/10.1016/j.ibusrev.2003.08.001

Edelman, L. F., Manolova, T. S., \& Brush, C. G. (2008). Entrepreneurship Education: Correspondence between Practices of Nascent Entrepreneurs and Textbook Prescriptions for Success. Academy of Management Learning \& Education, 7, 56-70.

https://doi.org/10.5465/amle.2008.31413862

Fairoz, F. M., Hirobumi, T., \& Tanaka, Y. (2010). Entrepreneurial Orientation and Busi- 
ness Performance of Small and Medium Scale Enterprises of Hambantota District, Sri Lanka. Asian Social Science, 6, 34-46. https://doi.org/10.5539/ass.v6n3p34

Fatoki, O., \& Patswawairi, T. (2012). The Motivations and Obstacles to Immigrant Entrepreneurship in South Africa. Journal of Social Sciences, 32, 133-142. https://doi.org/10.1080/09718923.2012.11893059

Fiol, C. M. (1996). Squeezing Harder Doesn't Always Work: Continuing the Search for Consistency in Innovation Research. Academy of Management Review, 21, 1012-1021. https://doi.org/10.5465/amr.1996.15868543

Ford, J. D., \& Schellenberg, D. A. (1982). Conceptual Issues of Linkage in the Assessment of Organizational Performance. Academy of Management Review, 7, 49-58. https://doi.org/10.5465/amr.1982.4285450

Geroski, P., Machin, S., \& Van Reenen, J. (1993). The Profitability of Innovating Firms. Journal of Economics, 24, 198-211.

Ghana Tourism Authority (2011). Tourism Statistical Factsheet (Electronic Version). http://www.ghana.travel/ghana tourist board/

Grande, J., Madsen, E. L., \& Borch, O. J. (2011). The Relationship between Resources, Entrepreneurial Orientation and Performance in Farm-Based Ventures. Entrepreneurship and Regional Development, 23, 89-111. https://doi.org/10.1080/08985620903183710

Hair, J. F., Bush, R. P., \& Ortinau, D. J. (2003). Marketing Research. New York, NY: McGraw-Hill Higher Education.

Hameed, I. (2011). Impact of Entrepreneurial Orientation, Entrepreneurial Management and Environmental Dynamism on Firmâ $€^{\mathrm{Tm}} \mathrm{s}$ Financial Performance. Journal of Economics and Behavioral Studies, 3, 101-114. https://doi.org/10.22610/jebs.v3i2.260

Hart, S. L. (1992). An Integrative Framework for Strategy-Making Processes. Academy of Management Review, 17, 327-351. https://doi.org/10.5465/amr.1992.4279547

Hughes, M., \& Morgan, R. E. (2007). Deconstructing the Relationship between Entrepreneurial Orientation and Business Performance at the Embryonic Stage of Firm Growth. Industrial Marketing Management, 36, 651-661. https://doi.org/10.1016/j.indmarman.2006.04.003

Hult, G. T., Hurley, R. F., \& Knight, G. A. (2004). Innovativeness: Its Antecedents and Impact on Business Performance. Industrial Marketing Management, 33, 429-438. https://doi.org/10.1016/j.indmarman.2003.08.015

Irava, W., \& Moores, K. (2010). Resources Supporting Entrepreneurial Orientation in Multigenerational Family Firms. International Journal of Entrepreneurial Venturing, 2, 222-245. https://doi.org/10.1504/IJEV.2010.037110

Jiménez-Jiménez, D., \& Sanz-Valle, R. (2011). Innovation, Organizational Learning and Performance. Journal of Business Research, 64, 408-417. https://doi.org/10.1016/j.jbusres.2010.09.010

Johannessen, J. A. (2009). A Systemic Approach to Innovation: The Interactive Innovation Model. Kybernetes, 38, 158-176. https://doi.org/10.1108/03684920910930330

Keh, H. T., Nguyen, T. T. M., \& Ng, H. P. (2007). The Effects of Entrepreneurial Orientation and Marketing Information on the Performance of SMEs. Journal of Business Venturing, 22, 592-611. https://doi.org/10.1016/j.jbusvent.2006.05.003

Khandwalla, P. N. (1976/77). Some Top Management Styles, Their Context and Performance. Organization and Administrative Sciences, 7, 21-51.

Kreiser, P. M., \& Davis, J. (2010). Entrepreneurial Orientation and Firm Performance: 
The Unique Impact of Innovativeness, Proactiveness, and Risk-Taking. Journal of Small Business \& Entrepreneurship, 23, 39-51. https://doi.org/10.1080/08276331.2010.10593472

Krejcie, R. V., \& Morgan, D. W. (1970). Determining Sample Size for Research Activities. Educational and Psychological Measurement, 30, 607-610. https://doi.org/10.1177/001316447003000308

Lachman, R., \& Wolfe, R. A. (1997). The Interface of Organizational Effectiveness and Corporate Social Performance. Business and Society, 36, 194-214. https://doi.org/10.1177/000765039703600205

Lee, C., Lee, K., \& Pennings, J. (2001). Internal Capabilities, External Networks and Performance: A Study on Technology Based Ventures. Strategic Management Journal, 22, 614-640. https://doi.org/10.1002/smj.181

Lee, S. M., \& Peterson, S. J. (2000). Culture, Entrepreneurial Orientation and Global Competitiveness. Journal of World Business, 35, 401-416. https://doi.org/10.1016/S1090-9516(00)00045-6

Lerner, M., \& Almor, T. (2002). Relationships among Strategic Capabilities and the Performance of Women-Owned Small Ventures. Journal of Small Business Management, 40, 109-125. https://doi.org/10.1111/1540-627X.00044

Lumpkin, G. T., \& Dess, G. G. (1996). Clarifying the Entrepreneurial Orientation Construct and Linking It to Performance. Academy of Management Review, 21, 135-172. https://doi.org/10.5465/amr.1996.9602161568

Lumpkin, G. T., \& Dess, G. G. (2001). Linking Two Dimensions of Entrepreneurial Orientation to Firm Performance: The Moderating Role of Environment and Industry Life Cycle. Journal of Business Venturing, 16, 429-451.

https://doi.org/10.1016/S0883-9026(00)00048-3

Lumpkin, G. T., Brigham, K. H., \& Moss, T. W. (2010). Long-Term Orientation: Implications for the Entrepreneurial Orientation and Performance of Family Businesses. Entrepreneurship \& Regional Development, 22, 241-264. https://doi.org/10.1080/08985621003726218

Madhoushi, M., Sadati, A., Delavari, H., Mehdivand, M., \& Mihandost, R. (2011). Entrepreneurial Orientation and Innovation Performance: The Mediating Role of Knowledge Management. Asian Journal of Business Management, 3, 310-316.

Malhotra, N. K., Agarwal, J., \& Peterson, M. (1996). Methodological Issues in Cross-Cultural Marketing Research: A State-of-the-Art Review. International Marketing Review, 13, 7-43. https://doi.org/10.1108/02651339610131379

McDaniel, J. C., \& Gates, R. (1996). Contemporary Marketing Research. San Francisco, CA: West Pub. Co.

Mensah, I. (2009). The Management of Tourism and Hospitality Services: Global Dimensions, Ghanaian Perspectives. Accra: Woeli Publishing Services.

Miller, D. (1983). The Correlates of Entrepreneurship in Three Types of Firms. Management Science, 29, 770-791. https://doi.org/10.1287/mnsc.29.7.770

Miller, D., \& Friesen, P. (1982). Innovation in Conservative and Entrepreneurial Firms: Two Models of Strategic Momentum. Strategic Management Journal, 3, 1-25. https://doi.org/10.1002/smj.4250030102

Miller, D., \& Shamsie, J. (1996). The Resource-Based View of the Firm in Two Environments: The Hollywood Film Studios from 1936 to 1965. Academy of Management Journal, 39, 519-543. 
Mintzberg, H. (1973). The Nature of Managerial Work. New York: Harper \& Row.

Moreno, A. M., \& Cassilass, J. C. (2008). Entrepreneurial Orientation and Growth of SMEs: A Causal Model. Entrepreneurship Theory and Practice, 32, 507-528. https://doi.org/10.1111/j.1540-6520.2008.00238.x

Mumford, M. D., \& Licuanan, B. (2004). Leading for Innovation: Conclusions, Issues, and Directions. The Leadership Quarterly, 15, 163-171. https://doi.org/10.1016/j.leaqua.2003.12.010

Naldi, L., Nordqvist, M., Sjöberg, K., \& Wiklund, J. (2007). Entrepreneurial Orientation, Risk Taking, and Performance in Family Firms. Family Business Review, 20, 33-40. https://doi.org/10.1111/j.1741-6248.2007.00082.x

Nunnally, J. C. (1978). Psychometric Theory (2nd ed.). New York: McGraw-Hill.

Palich, L. E., \& Bagby, D. R. (1992). Cognitive Processes: Is the Entrepreneur Different. Frontiers of Entrepreneurship Research, 106-117.

Pallant, J., \& Manual, S. S. (2007). A Step by Step Guide to Data Analysis Using SPSS for Windows. SPSS Survival Manual.

Palmer, T. B., \& Wiseman, R. M. (1999). Decoupling Risk Taking from Income Stream Uncertainty: A Holistic Model of Risk. Strategic Management Journal, 20, 1037-1062. https://doi.org/10.1002/(SICI)1097-0266(199911)20:11<1037::AID-SMJ67>3.0.CO;2-2

Penrose, E. T. (1959). The Theory of the Growth of the Firm. New York: John Wiley.

Peteraf, M. A. (1993). The Cornerstones of Competitive Advantage: A Resource-Based View. Strategic Management Journal, 14, 179-191. https://doi.org/10.1002/smj.4250140303

Poon, J. M., Ainuddin, R. A., \& Junit, S. H. (2006). Effects of Self-Concept Traits and Entrepreneurial Orientation on Firm Performance. International Small Business Journal, 24, 61-82. https://doi.org/10.1177/0266242606059779

Rauch, A., Unger, J. M., Frese, M., \& Rosenbusch, N. (2011). Human Capital and Entrepreneurial Success: A Meta-Analytical Review. Journal of Business Venturing, 26, 341-358. https://doi.org/10.1016/j.jbusvent.2009.09.004

Schumpeter, J. A. (1934). The Theory of Economic Development (R. Opie, Trans.). Harvard: Economic Studies, 46, 1600-0404.

Sexton, D. L., \& Bowman-Upton, N. B. (1991). Entrepreneurship: Creativity and Growth. New York: Macmillan Pub Co.

Sharma, A., \& Dave, S. (2011). Entrepreneurial Orientation: Performance Level. SCMS Journal of Indian Management, $8,43$.

Sharma, A., \& Lacey, N. (2004). Linking Product Development Outcomes to Market Valuation of the Firm: The Case of the Pharmaceutical Industry? Journal of Product Innovation Management, 21, 297-308. https://doi.org/10.1111/j.0737-6782.2004.00084.x

Sitkin, S. B., \& Pablo, A. L. (1992). Reconceptualizing the Determinants of Risk Behaviour. Academy of Management Review, 17, 9-38.

https://doi.org/10.5465/amr.1992.4279564

Slovic, P. (1993). Perceived Risk, Trust, and Democracy. Risk Analysis, 13, 675-682. https://doi.org/10.1111/j.1539-6924.1993.tb01329.x

Smart, D. T., \& Conant, J. S. (1994). Entrepreneurial Orientation, Distinctive Marketing Competencies and Organizational Performance. Journal of Applied Business Research (JABR), 10, 28-38. https://doi.org/10.19030/jabr.v10i3.5921

Soininen, J., Martikainen, M., Puumalainen, K., \& Kyläheiko, K. (2012). Entrepreneurial Orientation: Growth and Profitability of Finnish Small and Medium-Sized Enterprises. 
International Journal of Production Economics, 140, 614-621. https://doi.org/10.1016/j.ijpe.2011.05.029

Standing, C., \& Kiniti, S. (2011). How Can Organisations Use Wikis for Innovation? Technovation, 31, 287-295. https://doi.org/10.1016/j.technovation.2011.02.005

Stinchcombe, A. L. (1965). Social Structure and Organizations. In J. G. March (Ed.), Handbook of Organizations (pp. 142-193). New York: Rand McNally.

Su, Z., Xie, E., \& Li, Y. (2011). Entrepreneurial Orientation and Firm Performance in New Ventures and Established Firms. Journal of Small Business Management, 49, 558-577. https://doi.org/10.1111/j.1540-627X.2011.00336.X

Swierezek, F., \& Thai, T. (2003). Motivation, Entrepreneurship and the Performance of SMEs in Vietnam. Journal of Enterprising Culture, 11, 47-68. https://doi.org/10.1142/S0218495803000044

Tabachnick, B. G., \& Fidell, L. S. (2007). Using Multivariate Statistics (2nd ed.). Boston, MA: Pearson.

Tang, Z., \& Tang, J. (2012). Entrepreneurial Orientation and SME Performance in China's Changing Environment: The Moderating Effects of Strategies. Asia Pacific Journal of Management, 29, 409-431. https://doi.org/10.1007/s10490-010-9200-1

Thaler, R. H., \& Johnson, E. J. (1990). Gambling with House Money and Trying to Break Even: The Effects of Prior Outcomes on Risky Choice. Management Science, 36, 643-660. https://doi.org/10.1287/mnsc.36.6.643

Thornhill, S., \& Amit, R. (2003). Growth management of emergent firms in Canada. In P. Reynolds et al. (Eds.), Frontiers of Entrepreneurship Research (pp. 381-392). Babson Park, MA: Babson College.

Van de Ven, A. H., \& Poole, M. S. (1995). Explaining Development and Change in Organizations. Academy of Management Review, 20, 510-540.

https://doi.org/10.5465/amr.1995.9508080329

Varis, M., \& Littunen, H. (2010). Types of Innovation, Sources of Information and Performance in Entrepreneurial SMEs. European Journal of Innovation Management, 13, No. 2. https://doi.org/10.1108/14601061011040221

Venkatraman, N. (1989). The Concept of Fit in Strategy Research: Toward Verbal and Statistical Correspondence. Academy of Management Review, 14, 423-444.

https://doi.org/10.5465/amr.1989.4279078

Wang, C. L. (2008). Entrepreneurial Orientation, Learning Orientation, and Firm Performance. Entrepreneurship Theory and Practice, 32, 635-657. https://doi.org/10.1111/j.1540-6520.2008.00246.x

Wernerfelt, B. (1995). The Resource-Based View of the Firm: Ten Years after. Strategic Management Journal, 16, 171-174. https://doi.org/10.1002/smj.4250160303

Wiklund, J. (1999). The Sustainability of the Entrepreneurial Orientation-Performance Relationship. Entrepreneurship Theory and Practice, 24, 37-48. https://doi.org/10.1177/104225879902400103

Wiklund, J., \& Shepherd, D. (2003). Knowledge-Based Resources, Entrepreneurial Orientation, and the Performance of Small and Medium-Sized Businesses. Strategic Management Journal, 24, 1307-1314. https://doi.org/10.1002/smj.360

Wiklund, J., \& Shepherd, D. (2005). Entrepreneurial Orientation and Small Business Performance: A Configurational Approach. Journal of Business Venturing, 20, 71-91. https://doi.org/10.1016/j.jbusvent.2004.01.001

Wolfe, J., \& Bruton, G. (1994). On the Use of Computerized Simulations for Entrepre- 
neurship Education. Simulation \& Gaming, 25, 402-415.

https://doi.org/10.1177/1046878194253007

World Travel and Tourism Council (2011). Annual Report. https://mtu.gov.hu/documents/prod/1129 traveltourism2011.pdf

Yeboah, M. A. (2011). Entrepreneurial Orientation and Business Performance of Auto Artisans at Siwdu in the Cape Coast Metropolis. Unpublished Master of Business Administration Thesis, Cape Coast: University of Cape Coast.

Yusuf, A. (2002). Environmental Uncertainty, the Entrepreneurial Orientation of Business Ventures and Performance. International Journal of Change Management, 12, 83-103. https://doi.org/10.1108/eb047454 